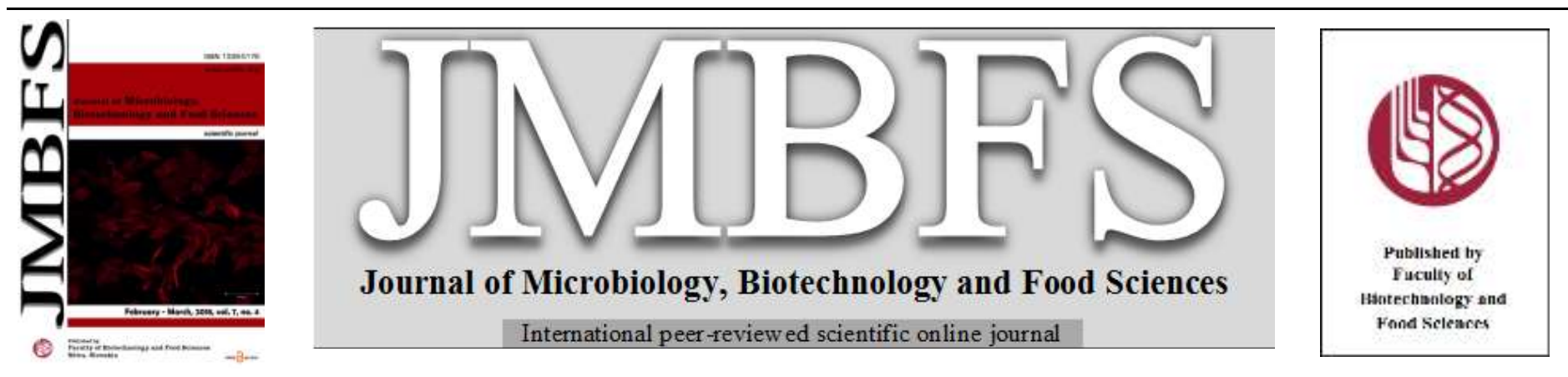

\title{
AMINO ACID ASPARAGINE INTAKE THROUGH MILK ENRICHED WITH SUPPLEMENTS
}

\section{Suzana Stojanovska $*^{1}$, Julijana Tomovska ${ }^{1}$, Aleksandar Krstanovski ${ }^{l}$, Jasmina Tasevska ${ }^{1}$, Mirjana Menkovska ${ }^{2}$}

\author{
Address(es): M.Sc. Suzana Stojanovska, \\ ${ }^{1}$ University “St. Kliment Ohridski”, Faculty of Biotechnical Sciences, Partizanska b.b., 7000 Bitola, Macedonia. \\ ${ }^{2}$ University "Ss.Cyril and Methodius", Institute of Animal Science, Department of Food technology and Biotechnology, Blvd. Ilinden. 92 -a, 1001 Skopje, Macedonia.
}

*Corresponding author: stojanovskasuzana@gmail.com

doi: 10.15414/jmbfs.2018.7.4.392-394

\section{ARTICLE INFO}

Received 20.7. 2017

Revised 13. 12. 2017

Accepted 2.1.2018

Published 1. 2. 2018

Regular article

orten Acctss

\begin{abstract}
Considering that some of milk beverages contain various types of additives like coffee or chicory as healthier option, the aim of this research is to examine if milk beverages could serve as additional source of asparagine, which could support the body to meet needs for dispensable amino acids. For the purpose of asparagine content determination, the choice fell on the method based upon redox reaction of asparagine with potassium permanganate, $\mathrm{KMnO}_{4}$. The values show that the concentration of asparagine in the milk samples with chicory as an additive is higher $(0.98-1.07 \mathrm{mg} / \mathrm{l})$, in comparison with milk samples without additives where lower asparagine concentrations $(0.26-0.40 \mathrm{mg} / \mathrm{l})$ can be observed. Taking into account the above presented results it can be concluded that in addition to the specified amount of amino acids the consumer receives through milk, certain amounts of dispensable amino acids can be entered through supplements, as it is the case with asparagine from coffee or chicory.
\end{abstract}

Keywords: additives, asparagine, chicory, coffee, milk

\section{INTRODUCTION}

Milk as a food product possesses high nutritional value, especially due to the balance between organic substances which it is composed of and which are divided into building blocks, i.e. proteins and energy components or carbohydrates and fats (Guetouache $\boldsymbol{e t}$ al. 2014). Within its structure it integrates two protein types: casein $(80 \%)$ and whey $(20 \%)$. Their ability to support main protein roles in the body is based on the fact that both contain sufficient amounts of all essential amino acids, which, according to science-based rating, classifies them as high-quality proteins. (Bos et al. 2000; Philips et al. 2009). Drinking one glass of milk $(200 \mathrm{ml}) 6.8 \mathrm{~g}$ of daily protein needs are met. In this respect modern-day dairy industry went one step forward and brought to the market an entire range of dairy beverages, enriched with different types of flavours and additives, which when consumed instead of classical meal or as dietary supplements provide us with even more of healthy nutrients.

Successfully satisfying the metabolic demand requires from protein adequate amounts of nutritionally essential (indispensable) and digestible amino acids and amino acids that under particular conditions can become essential. Another prerequisite for this is presence of sufficient total amino acid nitrogen, which may be provided from the essential amino acids, dispensable amino acids and from other non-essential nitrogen sources as well (WHO, 2007).

L-Asparagine, the amide of the dicarboxylic amino acid aspartic acid, is a dispensable amino acid that is either a subject of deamination during food processing or undergoes a mucosal cells aspartate conversion process. Daily human intakes of L-asparagine from dietary protein are about $7.4 \mathrm{~g} / 100 \mathrm{~g}$ of dietary protein. (DRI, 2005)

Many authors researched asparagine effects on human health. Some of them reported that supplementing a low intensity exercise with branched chain amino acids, like aspartate and asparagine, resulted in enhanced physical performance. According to these authors, "the amino acids interfered with the mechanisms responsible for the onset of fatigue, specifically with muscular and hepatic glycogen depletion and the synthesis of 5-hidroxytryptamine in low intensity physical activities" (Marquezi et al. 2003). Other authors speculate that asparagine supplementation in glutamine-deprived cells is also able to suppress cell death, which emphasizes its importance and role in overcoming and cellula adaptation to metabolic stresses, such as glutamine depletion (Hettmer et al. 2015).

Considering that some of milk beverages contain various types of additives like coffee or chicory as healthier option, the aim of this research is to examine if milk beverages could serve as additional source of asparagine, which could support the body needs for dispensable amino acids. Coffee and chicory are both old plant species, known and used since a long time ago. (Anthony $\boldsymbol{e t}$ al. 2010; Quanzhen and Jian, 2011). Coffee represents the primary source of wealth in many tropical countries and chicory, known and used already in the ancient Egypt, is lately being increasingly used as a substitution for coffee. This is mainly due to the fact that it does not contain caffeine, does not cause addiction and effects the human organism almost in the same way as coffee does.

Asparagine and metabolic processes such as asparagine synthetase, which occur in the human body, as well as the effect they have on human health, are still the subject of research of many scientists (Hinchman et al. 1992; Matsui et al. 1992; Tessmann et al. 1999; Toma et al. 2011).

\section{MATERIAL AND METHODS}

\section{Materials and apparatus}

Different milk types, with grounded coffee and roasted chicory acting as additives added under laboratory conditions, were used in order to conduct this research. All these ingredients were purchased at the retail stores. Prior to comparing final results, the analysis of blank samples was also carried out. All chemicals used for this examination had analytical reagent grade and spectral analysis were conducted on Spectroquant Pharo 300, UV/VIS spectrophotometer with wavelength range $190-1100 \mathrm{~nm}$, using $1-\mathrm{cm}$ glass cell. Instrument used to carry out sample purification after fat and protein extraction was Hettich 320R centrifuge and $\mathrm{pH}$ measurements for acidity adjustment were performed on Schott lab860.

\section{Method}

For the purpose of asparagine content determination, the choice fell on the method based upon redox reaction of asparagine with potassium permanganate, $\mathrm{KMnO}_{4}$. This is mainly due to its property to serve as an oxidizing agent for the oxidation of carbon-carbon double bonds.

With exception of few modifications, sample preparation complied with the method described by Fahre and Ibrahim (2014). Milk dilution using $\mathrm{dH}_{2} \mathrm{O}$ in 1:10 ratio was followed by heating to $37^{\circ} \mathrm{C}$, after which it was transferred to centrifuge tubes, $10 \mathrm{ml}$ each. After separating the tubes into two groups of five tubes, $0.05 \mathrm{~g}$ of grounded coffee and chicory into four tubes of both groups were added, followed by thorough mixing of the sample. Fat extraction was carried out at room temperature, centrifuging the samples at $4000 \mathrm{rpm}$ for 10 minutes. To 
extract the protein, supernatants were treated with $20 \mathrm{ml}$ of $1 \mathrm{M} \mathrm{HClO}_{4}$ solution and centrifuged at $20^{\circ} \mathrm{C}$ and $9000 \mathrm{rpm}$ for three minutes. After transferring the supernatants into $200 \mathrm{ml}$ tubes and adjusting their $\mathrm{pH}$ values to $\mathrm{pH}=8$ by adding $2 \mathrm{M} \mathrm{NaOH}$ solution, tubes were placed into the freezer for the duration of 20 minutes in order to precipitate sodium perchlorate and separate some eventually present fats. Finally, sample centrifugation at $4000 \mathrm{rpm}$ and room temperature took place, lasting 10 minutes. This was followed by transferring $1 \mathrm{ml}$ from each supernatant to the $25 \mathrm{ml}$ volumetric flask and by its reaction with $7 \mathrm{ml} \mathrm{1,6} \mathrm{x} \mathrm{10-3}$ $\mathrm{M} \mathrm{KMnO}_{4}$ and $1.5 \mathrm{ml}$ buffer solution with $\mathrm{pH}=10$. The volumetric flask was then filled with $\mathrm{dH} 2 \mathrm{O}$ to the marking. In order to accelerate the reaction, the samples were heated for 10 minutes, then immediately cooled to room temperature. Spectrophotometer at a wavelength of $405 \mathrm{~nm}$ was used to read the samples.

Standard solutions used to determine calibration curve were previously prepared through further dilution of basic solutions, as mentioned previously in the text. These solutions were treated with $\mathrm{KMnO} 4$ and buffer solution and samples were read at the same wavelength appropriate for the investigated substance. In the process of defining calibration curve, during the sample analysis the blank sample was also used.

\section{RESULTS AND DISCUSSION}

The concentration plotted on the abscissa and the absorbance of the standard solutions on the ordinate reflect the values of the asparagine calibration curve along with regression constants, presented in figure 1 . The existence of the proportional dependence, i.e. of very high positive correlation, can be demonstrated through the values of coefficients $(\mathrm{R})$ and their squares $\left(\mathrm{R}^{2}\right)$, which is the case with our values.
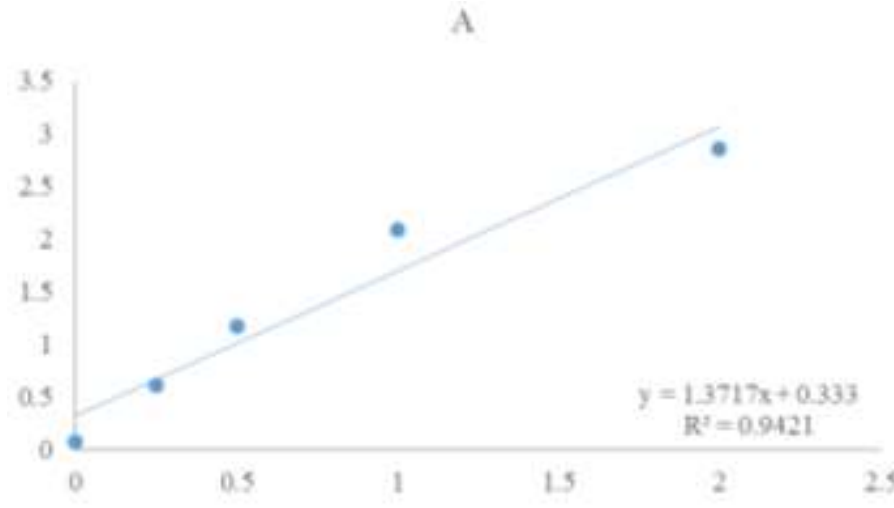

Figure 1 Calibration curve for asparagine

Table 1 presents the average values of asparagine concentration in all examined milk types, obtained by statistical data processing. For the amount of asparagine examined, the highest concentrations refer to the samples from various samples of milk in which chicory acted as an additive.

Table 1 Asparagine average values in examined milk samples

\begin{tabular}{lccc}
\hline & $\begin{array}{c}\text { milk samples } \\
\mathrm{C}_{4} \mathrm{H}_{8} \mathrm{~N}_{2} \mathrm{O}_{3}\end{array}$ & $\begin{array}{c}\text { milk samples } \\
\text { with ground } \\
\text { without additives }\end{array}$ & $\begin{array}{c}\text { milk samples } \\
\text { with chicory }\end{array}$ \\
\cline { 2 - 4 } & & $\mathrm{c}$ & \\
\hline $\bar{x}$ & 0.33 & 0.63 & 1.04 \\
$S T D$ & 0.07 & 0.09 & 0.05 \\
$\% R S D$ & 21.07 & 14.15 & 4.76 \\
\hline
\end{tabular}

Legend: $\mathrm{c}-$ concnentration

According to the previous studies these values are acceptable, given the fact that in their roots plants store asparagine and glutamine as final products of nitrogen assimilation. Soluble asparagine accumulates in most, if not all, of plant tissues during the low rates of protein synthesis and reduced levels of supplied nitrogen. The accumulation of asparagine occurs during normal physiological processes, such as seed germination and nitrogen transport. The accumulation of asparagine is additionally caused by environmental stress, namely due to the mineral deficiency, drought, salts, toxic metals and attack of pathogenic bacteria (Lea $\boldsymbol{e}$ al. 2006).

The values presented in figure 2 show that the concentration of asparagine in the milk samples with chicory as an additive is higher $(0.98-1.07 \mathrm{mg} / \mathrm{l})$, in comparison with milk samples without additives where lower asparagine concentrations $(0.26-0.40 \mathrm{mg} / \mathrm{l})$ can be observed. In the chicory root glutamate glutamine and aspartate constitute around $65-70 \%$ of the total content of amino acids (Druart et al. 2000). According to Dhont et al. (2003), in the main roots of some plants the concentration of asparagine, proline, arginine and histidine increases from the beginning of August until the middle of January and they cumulatively comprise about $75 \%$ of total amino acids in the summer months and around $80-90 \%$ in winter.

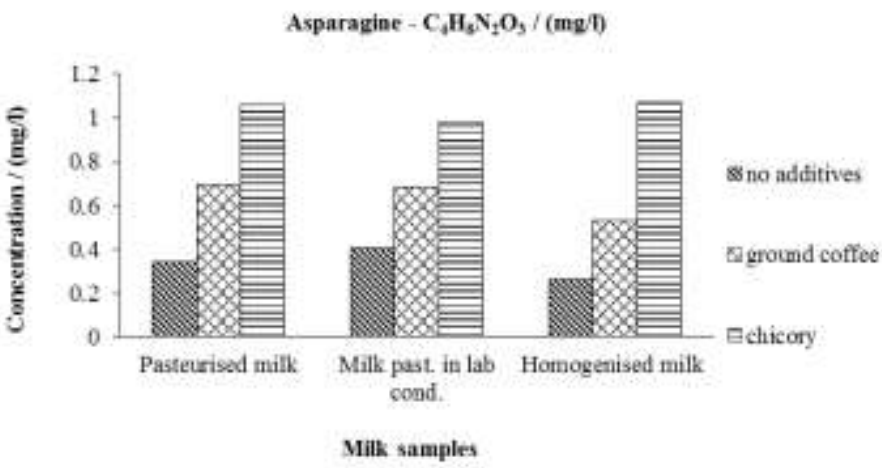

Figure 2 Asparagine quantities in examined milk samples

Unlike the samples with chicory, the samples with added ground coffee show lower values $(0.53-0.69 \mathrm{mg} / \mathrm{l})$, which is probably a result of previous processing of coffee. Amino acids content changes in green coffee beans after the processing in the pre-harvest period, such as drying, fermentation and storage. Also some observations made by Steinhart and Luger in 1995 showed that when exposed to steam treatment, significant decrease of free amino acids took place. Noticeable decrease in the amounts revealed that particularly affected by steam treatment at 0.8 bar are glutamic acid, asparagine, arginine, leucine, phenylalanine, tryptophan and lysine (Homma, 2001)

\section{CONCLUSION}

The combination of milk and coffee, also known as 'white coffee' and consumed mainly for breakfast, is included in the human diet for a long time now. Taking into account the above presented results it can be concluded that in addition to the specified amount of amino acids the consumer receives through milk, certain amounts of dispensable amino acids can be entered through supplements, as it is the case with asparagine from coffee or chicory. It is certainly still necessary to conduct additional research in order to explain in detail all the possible impacts of the consumption of these types of drinks.

\section{REFERENCES}

Anthony, F., Diniz, L. E. C., Combes, M.C., \& Lashermes, P. (2010). Adaptive radiation in Coffea subgenus Coffea L. (Rubiaceae) in Africa and Madagascar. Plant Systematics and Evolution, 285, 51-64. https://doi.org/10.1007/s00606009-0255-8

Bos, C., Gaudichon, C., \& Tome, D. (2000). Nutritional and physiological criteria in the assessment of milk protein quality for humans. Journal of American College Nutrition, 19(2), https://doi.org/10.1080/07315724.2000.10718068

Dhont, C., Castonguay, Y., Nadeau, P., Belange,r G., \& Chalifour, F. P. (2003) Alfalfa root nitrogen reserves and regrowth potential in response to fall harvests. Crop Science, 43, 181-194. https://doi.org/10.2135/cropsci2003.0181

Druart, N., Goupil, P., Dewaele, E., Boutin, J. P., \& Rambour, S. (2000). Nitrate assimilation in chicory roots (Cichorium intybus L.) which acquire radial growth Journal of Experimental Botany, 344(51), 539-546. https://doi.org/10.1093/jexbot/51.344.539

Fahre, N. A., \& Ibrahim B. (2014). Acrylamide in potato chips samples using different analytical techniques. Advance in Agriculture Biology, 1(1), 50-53. https://doi.org/10.15192/pscp.aab.2014.1.1.article8

Food and Nutrition Board, Institute of Medicine of the National Academies. (2005). Dietary reference intakes for energy, carbohydrate, fiber, fat, fatty acids, cholesterol, protein, and amino acids. Panel discussion. Washington DC, USA: National Academies Press.

Guetouache, M., Guessas, B., \& Medjekal, S. (2004). Composition and Nutritional value of raw milk. Issues in Biological Sciences and Pharmaceutical Research, 2(10), 115-122.

Hettmer, S., Schinzel, A. C., Tchessalova, D., Schneider, M., Parker, C. L., Bronson, R. T., Richards, N. G. J., Hahn, W. C., \& Wagers, A. J. (2015). Functional genomic screening reveals asparagine dependence as a metabolic vulnerability in sarcoma. eLife, 4:e09436, 1-17.

Hinchman, S. K., Henikoff, S., \& Schuster, M. (1992). A relationship between asparagine synthetase A and aspartyl t RNA synthetase. Journal of Biological Chemistry, 267(1), 144-149. 
Homma, S. (2001). Chemistry II: Non-volatile compounds, Part II. Clarke RJ. et al., (eds). Coffee: Recent developments. Blackwell science Ltd. https://doi.org/10.1002/9780470690499.ch2

Lea, J. P., Sodek, L., Parry, M. A. J., Shewry, P. R., \& Halford, N. G. (2006) Asparagine in plants. Annals of Applied Biology, 150, 1-26.

Marquezi, M. L., Roschel, H. A., Costa, A.S., Sawada, L. A., \& Lancha, A. H. (2003). Effect of aspartate and asparagine supplementation on fatigue determinants in intense exercise. International Journal of Sport Nutrition and Exercise Metabolism, 13, 65-75. https://doi.org/10.1123/ijsnem.13.1.65

Matsui, T., Titani, K., \& Mizuochi, T. (1992). Structures of the asparagine-linked oligosaccharide chains of human von Willebrand factor. Journal of Biological Chemistry, 267(13), 8723-8731.

Phillips, S. M., Tanq, J. E., \& Moore, D. R. (2009). The role of milk- and soybased protein in support of muscle protein synthesis and muscle protein accretion in young and elderly persons. Journal of American College Nutrition, 28(4), 343 354. https://doi.org/10.1080/07315724.2009.10718096

Quanzhen, W., \& Jian, C. (2011). Perspectives and utilization technologies of chicory (Cichorium intybus L.): A review. African Journal of Biotechnology, 10(11), 1966-1977.

Report of a joint WHO/FAO/UNU Expert Consultation. (2007). Protein and amino acid requirements in human nutrition. WHO technical report series 935. Geneva, Switzerland: WHO Press. Retrieved from

http://apps.who.int/iris/bitstream/10665/43411/1/WHO TRS 935 eng.pdf?ua=1 Tessmann-Barbosa, I. P., Pineda, V. L., Nick, H. S., Schuster, S. M., \& Kilberg, M. S. (1999). Transcriptional regulation of the human asparagine synthetase gene by carbohydrate availability. Biochemical Journal, 339, 151-158. https://doi.org/10.1042/0264-6021:3390151

Toma, J., Weinheimer, S. P., Stawiski, E., Whitcomb, J. M., Lewis, S. T., Petropoulos, C. J., \& Huang, W. (2011). Loss of asparagine-linked glycosylation sites in variable region 5 of human immunodeficiency virus type 1 envelope is associated with resistance to CD4 antibody ibalizumab. Journal of Virology, 85(8), 3872-3880. https://doi.org/10.1128/jvi.02237-10 